\title{
The use of soil parameters in predicting weed infestation in Maize (Zea mays L.)
}

\author{
Gabriel Olulakin Adesina*a, Yetunde Bunmi Oyeyiola ${ }^{\mathrm{b}}$, \\ Kasali Amofe Adelasoye ${ }^{c}$ and Akinpelu Festus Akin ${ }^{d}$ \\ Ladoke Akintola University of Technology, P. M. B. 4000, Ogbomoso, Nigeria. \\ E-mail address: aolulakinadesina@gmail.com, byboyeyiola@lautech.edu.ng, \\ ckaadelasoye@lautech.edu.ng, 'dfestusakindy@gmail.com
}

Key words: Weed, soil nutrients, organominerals, fertilizers, compost

\begin{abstract}
A field work was carried out to investigate the extent to which selected soil chemical properties can influence weed species distribution. There were sixteen treatments of two factors (Fertilizer type and weeding regimes) laid out in RCBD. The treatments included four fertilizer types; no fertilizer (F1), inorganic fertilizer - NPK 15:15:15 applied at $100 \mathrm{~kg} \mathrm{NPK} / \mathrm{ha}$ (F2), organic fertilizer - phosphocompost applied at $2.5 \mathrm{t} /$ ha and organomineral $-50 \%$ NPK 15:15:15 plus $50 \%$ phosphocompost. Four weeding regimes: weedy treatment (W1), weeding once (W2), weeding twice (W3) and weed free (W4). Weed free and weed once significantly improved maize growth and yield parameter under inorganic and organomineral fertilizer types. Increasing soil $\mathrm{pH}$, organic carbon and available phosphorus significantly reduced total weed biomass with plot that received no fertilizer been responsible for highest weed population. In organic fertilizer treatment significantly reduced soil $\mathrm{pH}$ from the initial 6.5 to 6.0 though, it combination with weed once or weed twice gave highest grain yield. Better nutrition (in terms of improved soil nutrient especially macro nutrient and organic carbon) when combined with weeding once can ascertain proper weed management and sustainable maize production.
\end{abstract}

\section{INTRODUCTION}

There are innumerable reports on the inhibitory effects of weeds on crop plants [1] and weeds can cause crop yield reduction up to $90 \%$ [2] Weeds compete with crops for nutrients, sunlight and other essential components in the environment required for good crop development and lead to yield reduction of the choice crop plant [3].

A total of 263 weed species belonging to 38 families were found in crop fields in West Africa. Broad-leaved weeds $(72 \%)$ and grasses $(24 \%)$ dominated the total weed spectrum, whereas sedges (4\%) were minor, weed species richness per field was similar across all agroecological zones and averaged about 16 per field [4]. Unweeded fields in Nigeria produced between 17 and 30 tons per hectare of fresh weed weight [5]. Weeds cause about \$36 billion annual damage in the United States alone, unchecked, weeds effectively outcompete crops for resources and decrease the yield of food, feed, and fiber [6]. Weeds are persistent, adaptable, stress tolerant, competitive, and capable of extreme levels of reproduction More than 400 biotypes of weeds have evolved resistance to one or more of all the major groups of herbicides [7].

A good understanding of how plants alter the soil ecosystem is critical to the management of crop-weed interactions and the consequent impacts of weed management practices on soil quality. Weeds are often perceived as exerting only negative effects on crop growth through competition for limiting soil nutrients, water, and light, thus necessitating management practices aimed at reducing these effects. While there is ample evidence to support this perception [8], there is also an increasing body of theory [9] and experimental evidence [10] suggesting that the specific characteristics of the weed community (i.e., species composition and diversity of the weeds growing in a field) may affect the nature of crop-weed interactions, potentially offsetting or compounding the competitive effects of weeds on crops. 
Maize is one of the most important grains in Nigeria, not only on the basis of the number of farmers that engaged in its cultivation, but also in its economic value. Maize is a major important cereal being cultivated in the rainforest and the derived savannah zones of Nigeria. Maize has been in the diet of Nigerians for centuries [11] and it has been reported to contains $80 \%$ carbohydrate, $10 \%$ protein, $3.5 \%$ fiber and $2 \%$ mineral. Iron and Vitamin B are also present in maize [12], In industrialized countries, maize is largely used as livestock feed and as a raw material for industrial products, while in low-income countries, it is mainly used for human consumption [12].

In developing countries particularly Nigeria, weed problem has drastically reduced the interest of people in farming. While it causes great loss in yield, its control also requires more inputs in terms of cost and labour than any other farming activities thereby limiting the production capacity and output of farmers. Therefore, understanding the relationship between certain soil properties and specific weed species could act as a guide to the farmer for efficient weed control. Therefore, the specific objective for this research work is to study the extent to which a particular soil property or combination of soil properties can influence the population and distribution of selected weed species using maize as a case study.

\section{MATERIALS AND METHOD}

\section{Experimental site}

Soil sampling and analysis: The field work was carried out at the Teaching and Research farm of Ladoke Akintola University of Technology, Ogbomoso Oyo state Nigeria located on N08 $10^{\prime \prime}$ E04 ${ }^{\circ} 10^{\prime \prime}$. Six random samples from $(0-20) \mathrm{cm}$ soil depth were taken from the experimental site measuring $63 \mathrm{~m} \times 21 \mathrm{~m}$ prior to opening up. The samples were air dried, sieved through $2 \mathrm{~mm}$ sieve and bulked. Composite samples were analyzed for $\mathrm{pH}$ (in distilled water 1:2), available phosphorus (Bray- P), total Nitrogen, organic carbon, exchangeable bases, acidity ECEC, micronutrients and particle size analysis following the recommended procedures described in [13].

\section{Field work}

The field was ploughed twice followed by harrowing. It was laid out into sixteen plots of $4 \mathrm{~m}$ x $4 \mathrm{~m}$ in split plot designed with three replicates. The experiment included two factors: first been four fertilizer types including: no fertilizer (F1), inorganic fertilizer (F2) that received NPK 15:15:15 applied at the rate of $100 \mathrm{~kg} \mathrm{NPK} /$ ha equivalent to $1.1 \mathrm{~kg} / 16 \mathrm{~m}^{2}$, organic fertilizer (F3) which received phosphocompost (bone meal fortified compost) at $2.5 \mathrm{t} /$ ha equivalent to $4 \mathrm{~kg} / 16 \mathrm{~m}^{2}$ and Organomineral fertilizer treatment (F4) which received $50 \%$ of the application rates of inorganic and organic fertilizers, equivalent to $0.55 \mathrm{~kg}$ NPK 15:15:15 and $2 \mathrm{~kg}$ phosphocompost per $16 \mathrm{~m}^{2}$ plot.

The second factor was the weeding regimes including: weedy treatment (W1) where no weeding was carried out all through the field trial, weeding once treatment (W2) done at 3 weeks after sowing of the test crop (Maize), weeding twice (W3) done at 3 and 6 weeks after sowing of maize and weed free treatment (W4) that was weeded every week. The organic based treatments were applied to appropriate plots two weeks before sowing. The organic fertilizer was applied a day to sowing. Both fertilizer types were applied through incorporation method.

\section{Sowing and Agronomic practices}

Oba super, widely grown late maize maturing maize cultivar was the test crop. Three seeds were sown per hole at a spacing of $75 \mathrm{~cm} \times 50 \mathrm{~cm}$. maize seedling were thinned to two plants per stand at three weeks after sowing. Pre-emergence herbicide (Atrazine) was applied at equal rate of $2.5 \mathrm{~kg}$ a.i/ha to all plots a day after sowing of maize 


\section{Data collection}

There were three categories of data collection. First been agronomic data collected on the test crop. This commenced two weeks after sowing where plant height, number of leaves and leaf area were taken. Grain yield from each plot was taken at harvesting.

Soil data was the second category where soil $\mathrm{pH}$ was determined on fortnight. Available phosphorus, organic carbon and exchangeable bases were determined from soil samples collected at harvesting following procedure earlier mentioned.

Weed biomass data was the third category of data where weed biomass was assessed using a quadrant of $0.5 \times 0.5 \mathrm{~m}$. this was also done on fortnight basis.

\section{Data Analysis}

All the data collected were subjected to analysis of variance using SAS statistical package. Means were separated using Duncan Multiple Range Test at $p \leq 0.05$. Simple linear regression analysis was used to assess the relationship amongst selected soil, weed biomass and maize yield parameter.

\section{RESULTS AND DISCUSSION}

\section{Physical and chemical properties of the soil studied}

The soil studied is slightly acidic with pH 6.5 (Table 1). Organic carbon is greatly depleted in the soil with value as low as $0.64 \mathrm{~g} / \mathrm{kg}$. This brought about the very low nitrogen in the soil. The available phosphorus was also very low falling below the $10 \mathrm{mg} . \mathrm{kg}$ considered critical for south western Nigeria soil [14]. Exchangeable bases especially calcium was also very low resulting into very low ECEC. The soil was higher in sand fraction and classified to have sandy loam textural class.

Table 1: Initial soil physio-chemical properties.

\begin{tabular}{ccc}
\hline Parameters & $\begin{array}{c}\text { Value in soil } \\
(\mathbf{g} / \mathbf{k g})\end{array}$ & Critical Value * \\
\cline { 2 - 3 } Soil pH & 6.5 & 6.5 \\
Organic Carbon $(\mathrm{g} / \mathrm{kg})$ & 0.64 & 30.0 \\
Total Nitrogen $(\mathrm{g} / \mathrm{kg})$ & 0.055 & 1.5 \\
Available phosphorus $(\mathrm{mg} / \mathrm{kg})$ & 0.93 & 10.00 \\
Exchangeable Calcium $\left(\mathrm{cmol} / \mathrm{kg}^{-1}\right)$ & 0.76 & 2.00 \\
Exchangeable Magnesium $\left(\mathrm{cmol} / \mathrm{kg}^{-1}\right)$ & 0.21 & 0.40 \\
Available Potassium (mg/kg) & 0.11 & 0.20 \\
Exchangeable Acidity & 0.03 & - \\
Effective Cation Exchange Capacity & 1.25 & - \\
Sand & 800 & - \\
Silt & 120 & - \\
Clay & 80 & \\
\hline
\end{tabular}




\section{Effects of weeding regimes on maize growth and weed parameters}

Weeding regime did not significantly affected plant height until 6 and 8 weeks after sowing (WAS). Weed once and weed free treatment were responsible for the tallest plant height. These values were statistically superior to weedy and weed twice situations. Similar trend was observed with leaves area where significant variation across weeding regime were recorded. Weed free was responsible for largest leave area followed by weed once and weed twice. Weedy situation gave least values. All the weeding regimes gave statistically similar number of leaves with a range of 5.7 -14.5 across all the weeks of observation except the weedy situation where a range of 5.6 - 9.3 was recorded. The generally low growth parameter values recorded under weedy situation was due to the competition of the weeds with the test crop for space, nutrient and sunlight. This is in line with the findings of [8] that, weeds are often perceived as exerting negative effects on crop growth through competition for limiting soil nutrients, water, and light.

Total weed biomass reduced with increasing weeding regimes with weed free situation giving least value. Total weed biomass reduced with increasing weeks of sowing in weed free and weed twice situations. As expected, this value increased progressively in weedy situation as weeks of sowing increases. At 8 WAS however, weed once and weed twice treatments gave statistically similar values.

\section{Effects of fertilizer types on maize growth and weed parameters}

Of the fertilizer treatment, F2, the inorganic treatment was responsible for statistically highest growth parameter values followed by the organomineral treatment (F4). The organic treatment (F3) gave values that were statistically similar to F1 (no fertilizer treatment) although, with slightly higher values. The slow release of nutrient from this organic fertilizer into the soil solution of the highly nutrient degraded soil studies was responsible for this. The nutrients released however from the organic fertilizer was more likely to first be used for improving the state of the soil reaction and perhaps biological activities in the soil. This of course will translate into better performance in subsequent seasons when treatment application is continued.

The very high number of leaves, leaf area and stem height recorded under NPK 15:15:15 treatment which doubles the values recoded under organic treatments seems to be the major reason for its preference for use by many farmers since inorganic fertilizer like NPK 15:15:15 are fast nutrient releasing. Although, its continued use had been reported to result in detrimental effects on soil reaction and biological activities especially on organic carbon depleted soils just like the one studied [15].

\section{Combined effects of fertilizer types and weeding regimes on soil reaction, weed biomass and maize grain yield}

Inorganic fertilizer regardless the weeding regime significantly reduced soil $\mathrm{pH}$ below the untreated soil closely followed by organomineral treatment. The soil $\mathrm{pH}$ reduction was highest in the NPK 15:15:15 plot during 6 WAS with value dropping to 6.0 from 6.5 under weed twice situation. Acidulating potential of inorganic fertilizer had earlier been reported $[16,15]$. Conversely, organic fertilizer treatment was responsible for highest soil $\mathrm{pH}$ regardless the weeding regimes followed by untreated soil.

All the inorganic fertilizer treatment regardless the weeding regime gave highest significantly higher maize grain yield. W2F4 however gave highest maize grain yield which was not statistically different from those recorded from W2F2, W3F2 and W4F2. Maize grain yield of inorganic fertilizer treatment under weedy situation was however lower to other weeding regimes. Maize grain yield on organic fertilizer treated plot under weed once and twice situation were below those of inorganic and organomineral treatments. Grain yield of organic fertilizer under weed free situation was however statistically similar to inorganic fertilizer under weedy situation and organomineral under weed free situation. Surprisingly, no grain was obtained from plots that 
received no fertilizer and organic fertilizer under weedy situations. Showing the extent to which weed could adversely affecting crop yield in nutrient degraded soils.

\section{Contributions of selected soil chemical properties to weed biomass}

The results of the linear regression showed that the soil chemical properties considered including soil $\mathrm{pH}$, available $\mathrm{P}$, exchangeable $\mathrm{Ca}, \mathrm{Mg}$ and acidity and organic carbon reduced total weed biomass except exchangeable bases ( $\mathrm{Ca}$ and $\mathrm{Mg}$ ) that slightly increased it. Increasing available $\mathrm{P}$ concentration significantly contributed to reduction in total weed biomass followed by organic carbon. Available P contributed $58 \%$ and $62 \%$ to the variation in the total weed biomass reduction at 6 and 8 WAS respectively. The improved $\mathrm{P}$ nutrition in the treated soil seems to improve root formation of the test crop for better nutrient uptake which afforded it to efficiently compete with the weeds for nutrient uptake. The better root formation of the test crop over the weeds brought about low nutrient uptake by the weed and thus reduction in the weed performance. Organic carbon contribute $12 \%$ and $11 \%$ to variation in total weed reduction at 6 and 8 WAS respectively, while soil $\mathrm{pH}$ during 8 WAS contributed $11 \%$ to the variation in total weed biomass reduction.

\section{Contributions of selected soil chemical properties to maize grain yield}

The simple linear regression analysis amongst maize grain yield and selected soil chemical properties showed that soil pH (59\%), exchangeable $\mathrm{Mg}(24 \%)$ and organic carbon (12\%) contributed more to the variation observed in maize grain yield with only organic carbon having positive relationship with maize grain yield.

The improved soil $\mathrm{pH}$ to near neutral and slightly alkaline range especially by the organic based treatments might be responsible for the negative relationship of soil $\mathrm{pH}$ with grain yield. Since maize perform optimally at soil $\mathrm{pH}(6.2-6.5)$. The soil $\mathrm{pH}$ above this range might have caused antagonism of some macro nutrients such as phosphorus via fixation by calcium at this alkaline $\mathrm{pH}$ range. 
Table 2: Effect of weeding regimes and fertilizer types on maize growth parameters

\begin{tabular}{|c|c|c|c|c|c|c|c|c|c|c|c|c|}
\hline \multirow[t]{3}{*}{ Treatments } & \multicolumn{4}{|c|}{ Plants height $(\mathrm{cm})$} & \multicolumn{4}{|c|}{ Leaves area $(\mathrm{cm})$} & \multicolumn{4}{|c|}{ Number of leaves } \\
\hline & \multicolumn{12}{|c|}{ Time of sampling (Weeks after planting) } \\
\hline & 2 & 4 & 6 & 8 & 2 & 4 & 6 & 8 & 2 & 4 & 6 & 8 \\
\hline \multicolumn{13}{|l|}{$\begin{array}{l}\text { Weeding } \\
\text { regime }\end{array}$} \\
\hline W1 & $17.7 \mathrm{a}$ & $43.2 \mathrm{a}$ & $70.5 \mathrm{c}$ & $87.4 \mathrm{c}$ & $43.1 \mathrm{a}$ & $213.7 \mathrm{a}$ & $322.1 \mathrm{c}$ & $313.1 b$ & $5.6 \mathrm{a}$ & $8.6 b$ & $8.8 \mathrm{~b}$ & $9.3 \mathrm{c}$ \\
\hline $\mathrm{W} 2$ & $17.1 \mathrm{a}$ & $45.7 \mathrm{a}$ & $98.6 \mathrm{a}$ & $156.8 \mathrm{a}$ & $46.4 \mathrm{a}$ & $269.2 \mathrm{a}$ & $462.4 \mathrm{ab}$ & $566.4 \mathrm{a}$ & $5.7 \mathrm{a}$ & $9.9 \mathrm{a}$ & $11.5 \mathrm{a}$ & $14.4 \mathrm{a}$ \\
\hline W3 & $17.0 \mathrm{a}$ & $41.6 \mathrm{a}$ & $86.3 b$ & $137.9 \mathrm{~b}$ & $40.2 \mathrm{a}$ & $212.2 \mathrm{a}$ & $410.4 b$ & $531.4 \mathrm{a}$ & $5.6 \mathrm{a}$ & $9.3 \mathrm{a}$ & $11.3 \mathrm{a}$ & $13.5 b$ \\
\hline W4 & $18.3 \mathrm{a}$ & $40.5 \mathrm{a}$ & $98.7 \mathrm{a}$ & $158.5 \mathrm{a}$ & $43.9 \mathrm{a}$ & $264.6 \mathrm{a}$ & $482.7 \mathrm{a}$ & $582.7 \mathrm{a}$ & $5.7 \mathrm{a}$ & $9.8 \mathrm{a}$ & $11.9 \mathrm{a}$ & $14.5 \mathrm{a}$ \\
\hline \multicolumn{13}{|l|}{$\begin{array}{c}\text { Fertilizer } \\
\text { types }\end{array}$} \\
\hline F1 & $14.4 \mathrm{~b}$ & $30.7 b$ & $55.7 \mathrm{c}$ & $87.9 \mathrm{c}$ & $27.8 \mathrm{~b}$ & $129.2 \mathrm{c}$ & $253.1 \mathrm{c}$ & $380.5 b$ & $5.0 \mathrm{~b}$ & $7.9 b$ & $8.9 b$ & $11.9 b$ \\
\hline $\mathrm{F} 2$ & $20.8 \mathrm{a}$ & $54.3 \mathrm{a}$ & $124.3 \mathrm{a}$ & $191.3 \mathrm{a}$ & $57.4 \mathrm{a}$ & $364.7 \mathrm{a}$ & $607.8 \mathrm{a}$ & $660.6 a$ & $6.1 \mathrm{a}$ & $10.9 \mathrm{a}$ & $13.2 \mathrm{a}$ & $15.2 \mathrm{a}$ \\
\hline F3 & $15.6 b$ & $37.2 b$ & $61.4 \mathrm{c}$ & $90.5 \mathrm{c}$ & $31.6 b$ & $161.4 \mathrm{c}$ & $279.2 \mathrm{c}$ & $354.7 b$ & $5.4 \mathrm{~b}$ & $8.3 b$ & $9.2 \mathrm{~b}$ & $9.9 \mathrm{c}$ \\
\hline $\mathrm{F} 4$ & $19.4 \mathrm{a}$ & $48.9 \mathrm{a}$ & $112.8 \mathrm{~b}$ & $171.0 \mathrm{~b}$ & $56.8 \mathrm{a}$ & $304.3 \mathrm{~b}$ & $537.6 \mathrm{~b}$ & $397.9 a$ & $6.0 \mathrm{a}$ & $10.5 \mathrm{a}$ & $12.2 \mathrm{a}$ & $14.6 \mathrm{a}$ \\
\hline
\end{tabular}

Means followed by the same letter (s) in the same column are not significantly different by DMRT at $\mathrm{p}<0.05$

$\mathrm{W} 1=$ weedy, $\mathrm{W} 2=$ weed once, $\mathrm{W} 3=$ weed twice, $\mathrm{W} 4=$ weed free, $\mathrm{F} 1=$ control, $\mathrm{F} 2=$ inorganic, $\mathrm{F} 3=$ organic, $\mathrm{F} 4=$ organo-mineral.

Table 3: Effect of weeding regimes and fertilizer types on total weed biomass and spear grass population density

\begin{tabular}{|c|c|c|c|c|}
\hline \multirow[t]{3}{*}{ Treatments } & \multicolumn{4}{|c|}{ Total Weed biomass $\left(\mathrm{g} / \mathrm{m}^{2}\right)$} \\
\hline & \multicolumn{4}{|c|}{ Time of sampling (Weeks After Planting) } \\
\hline & 2 & 4 & 6 & 8 \\
\hline \multicolumn{5}{|c|}{ Weeding regime } \\
\hline $\mathrm{W} 1$ & $22.9 \mathrm{a}$ & $107.8 \mathrm{a}$ & $134.3 \mathrm{a}$ & $278.5 \mathrm{a}$ \\
\hline W2 & $23.7 \mathrm{a}$ & $58.5 b$ & $27.7 b$ & $49.8 b$ \\
\hline W3 & $35.0 \mathrm{a}$ & $7.3 \mathrm{c}$ & $24.0 \mathrm{bc}$ & $32.3 b$ \\
\hline W4 & $6.1 \mathrm{a}$ & $5.6 \mathrm{c}$ & $2.8 \mathrm{c}$ & $1.0 \mathrm{~b}$ \\
\hline \multicolumn{5}{|c|}{ Fertilizer types } \\
\hline $\mathrm{F} 1$ & $32.1 \mathrm{a}$ & $35.9 \mathrm{~b}$ & $41.1 \mathrm{a}$ & $80.2 \mathrm{~b}$ \\
\hline F2 & $13.6 b$ & $35.8 b$ & $47.2 \mathrm{a}$ & $146.7 \mathrm{a}$ \\
\hline F3 & $24.9 \mathrm{ab}$ & $71.3 \mathrm{a}$ & $44.5 \mathrm{a}$ & $69.9 b$ \\
\hline F4 & $17.1 \mathrm{~b}$ & $36.2 \mathrm{a}$ & $56.0 \mathrm{a}$ & $64.9 \mathrm{~b}$ \\
\hline
\end{tabular}

Means followed by the same letter (s) in the same column are not significantly different by DMRT at $\mathrm{p}<0.05$. $\mathrm{W} 1=$ weedy, $\mathrm{W} 2=$ weed once, $\mathrm{W} 3=$ weed twice, $\mathrm{W} 4=$ weed free, $\mathrm{F} 1=\mathrm{control}$, $\mathrm{F} 2=$ inorganic, $\mathrm{F} 3=$ organic, $\mathrm{F} 4=$ organo-mineral. 
Figure 1a

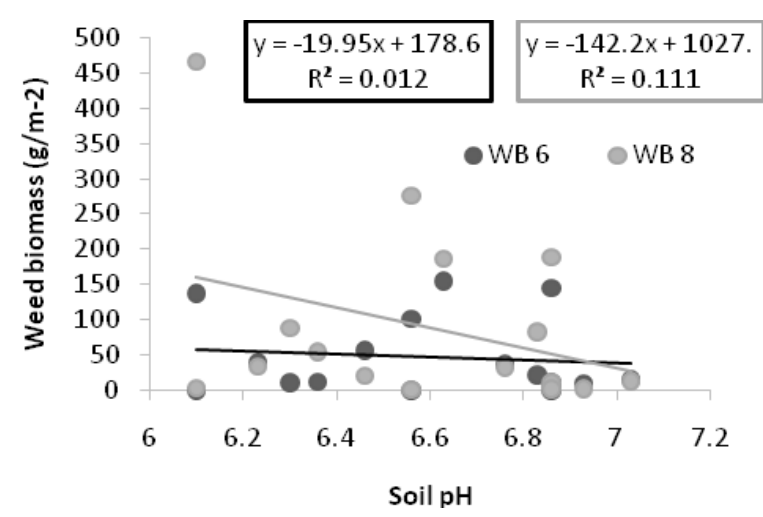

Figure $1 \mathrm{~b}$

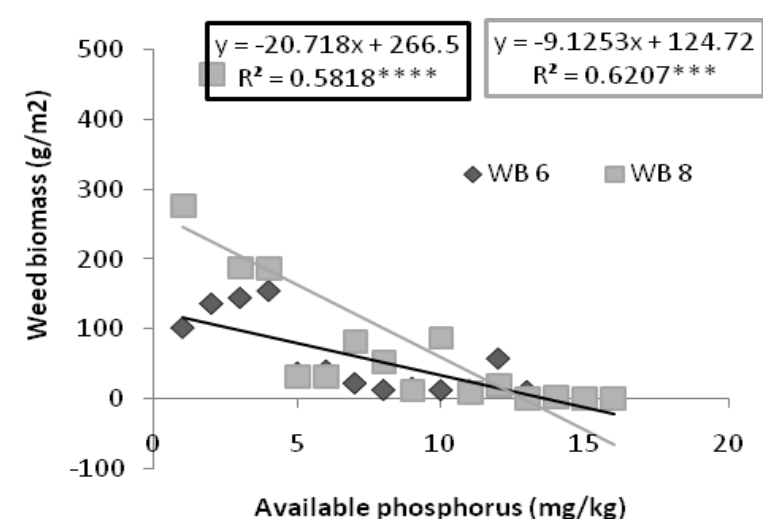

Figure 1c

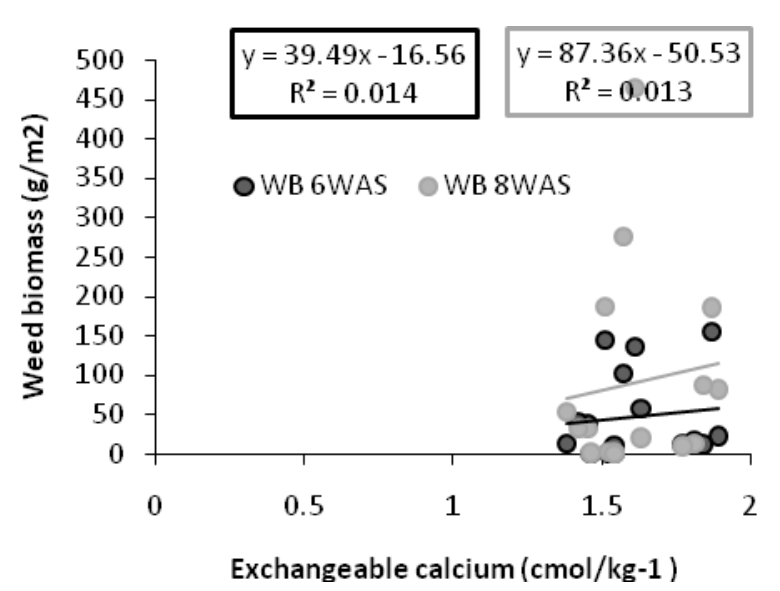

Figure 1d

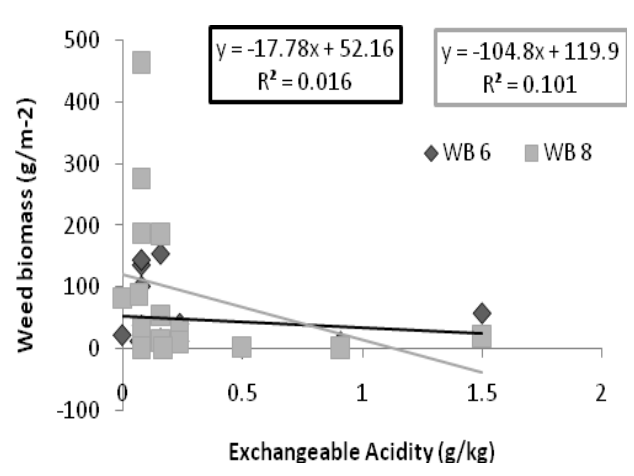

Figure 1e

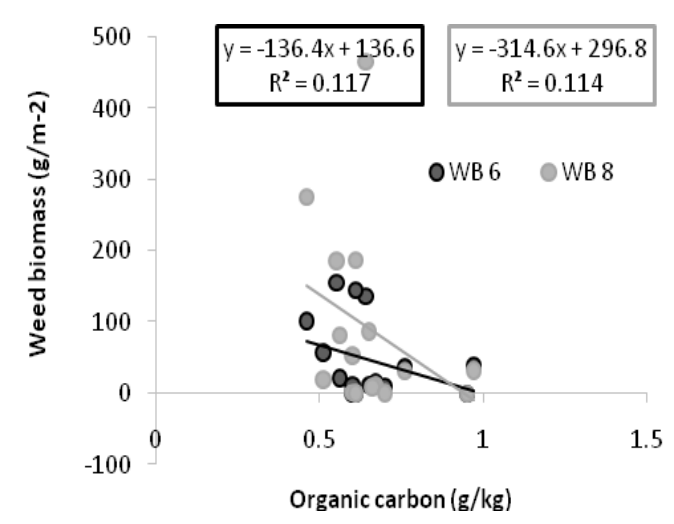

Figure 1f

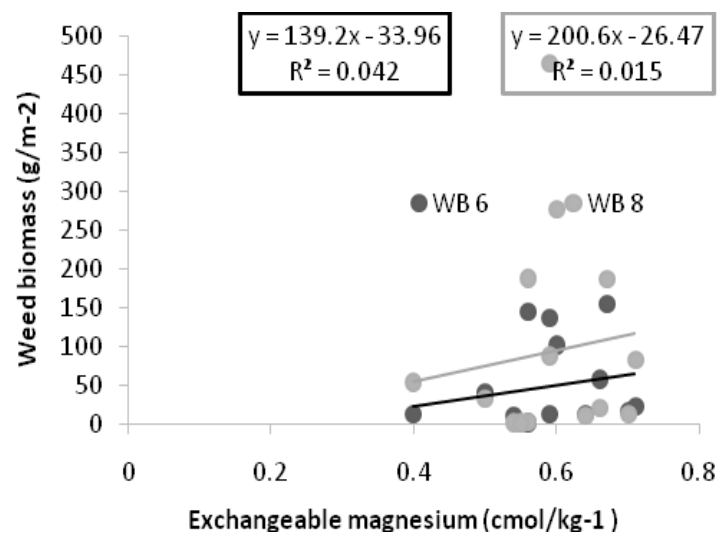

Figure 1a-f: The different soil nutrient components on weed biomass at 6 and 8 Weeks After Sowing. 
Figure $2 \mathrm{a}$

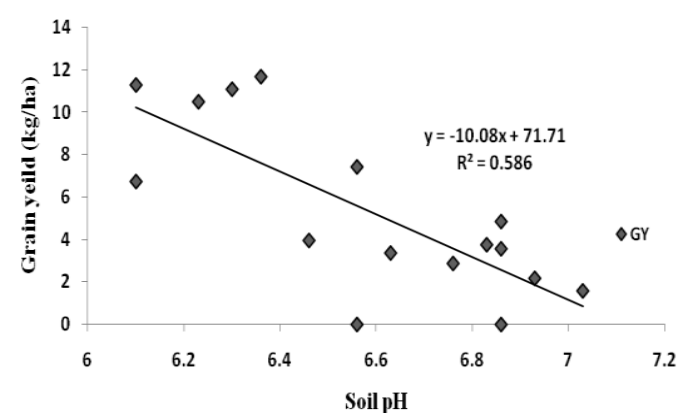

Figure $2 b$

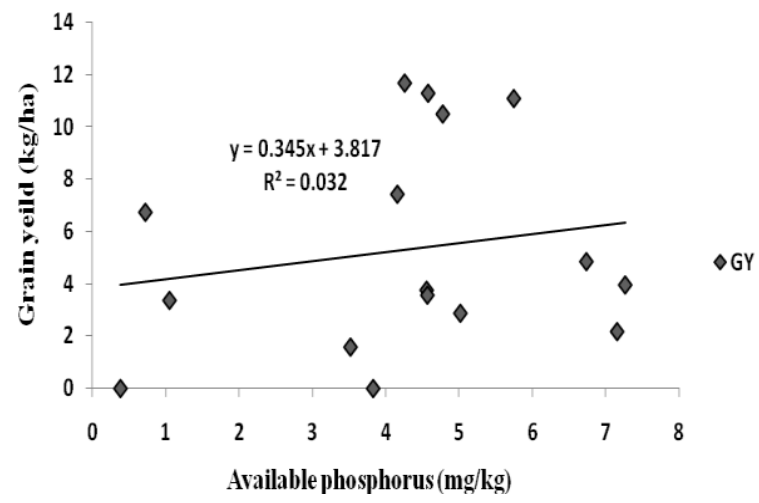

Figure 2c

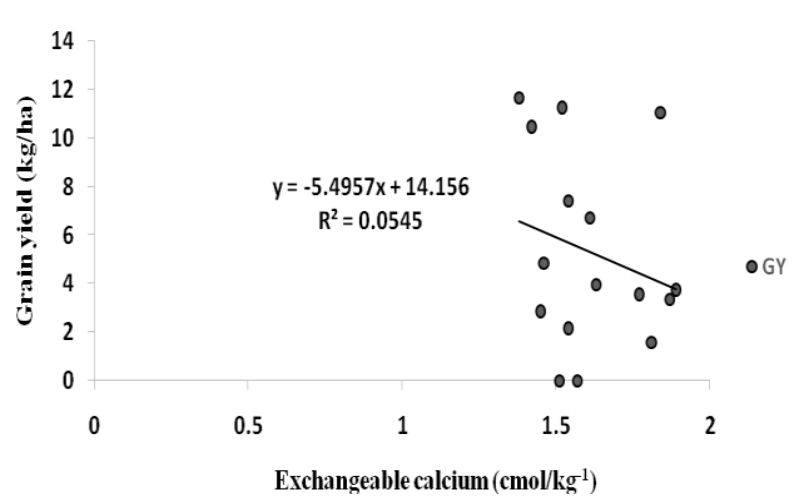

Figure $2 d$

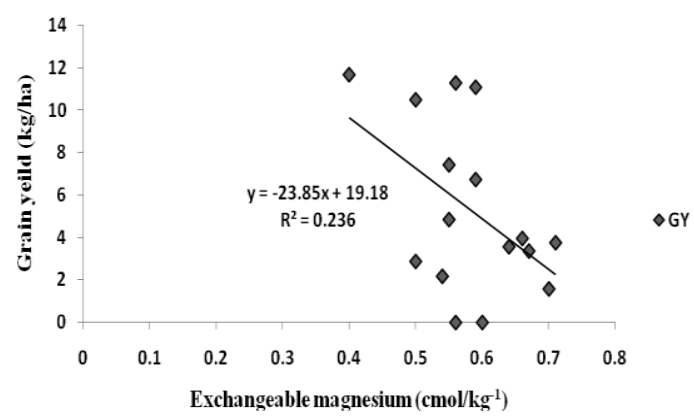

Figure 2e

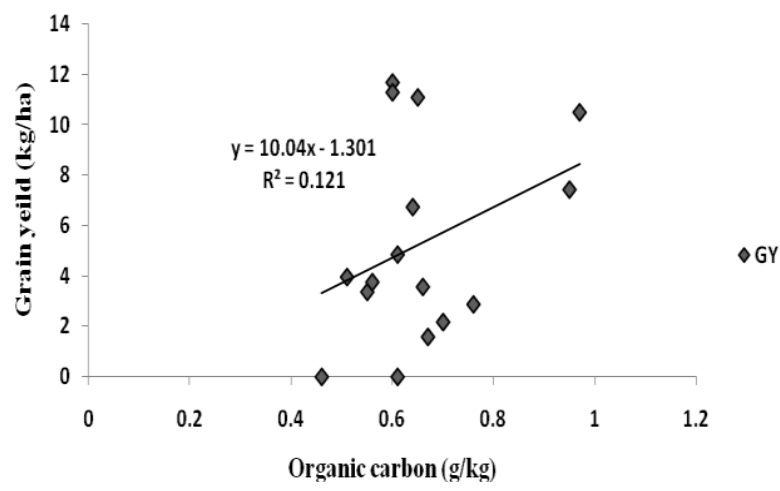

Figure $2 \mathrm{f}$

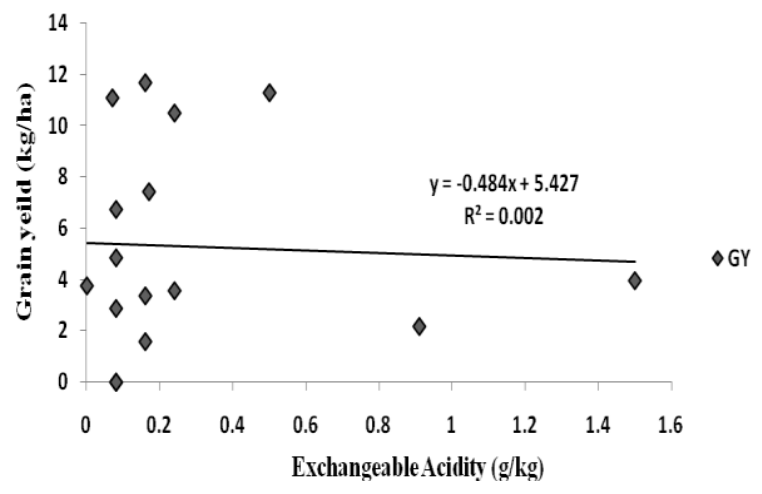

Figure 2a-f: The different soil nutrient components on weed biomass at 6 and 8 Weeks After Sowing. 


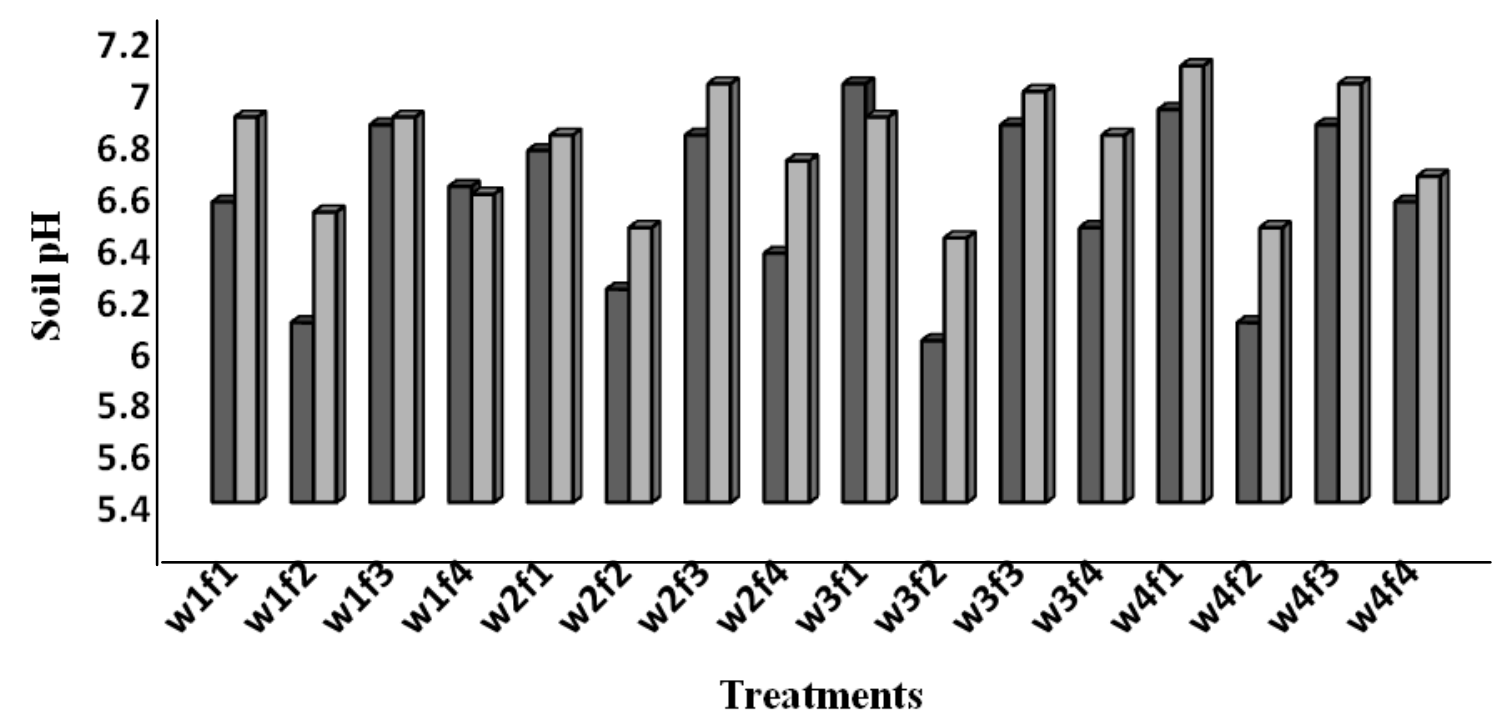

口Soil pH 8WAS $\quad$ QSoil PH 12WAS

Figure 3: The effect of Exchangeable magnesium on grain yield.

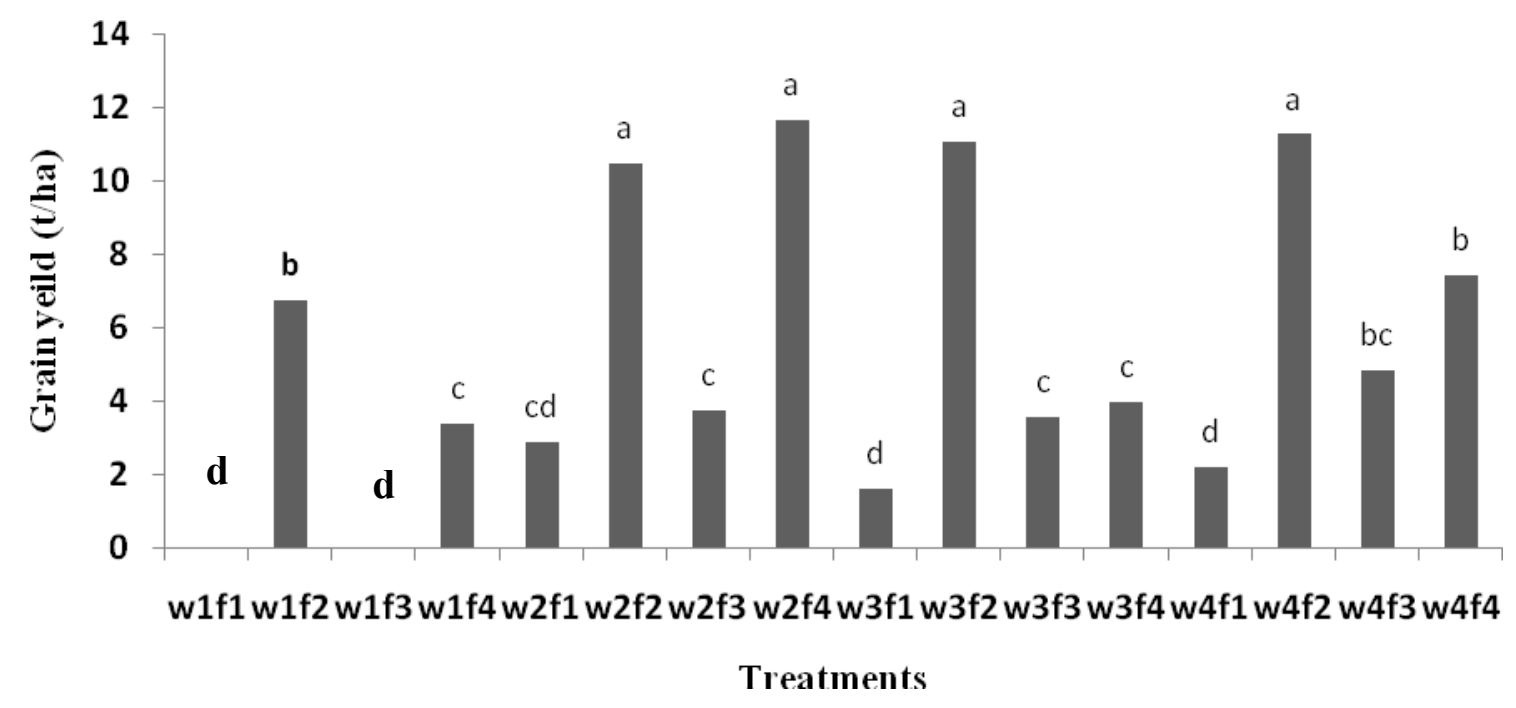

Figure 4: The effect of different level of treatments on grain yield.

\section{Conclusions}

Inorganic treatment though improved maize grain yield at this stage of the experiment, its continued use notwithstanding is likely to increase soil acidification and weed biomass infestation under long term trial. The organic treatment could not ascertain higher grain yield at this stage of the work although with improved soil reaction. The present results had shown that the $2.5 \mathrm{t} / \mathrm{ha}$ rate (coupled with its low nitrogen content) used for this trial was not sufficient for maize production on this highly degraded soil.

Two weeding regime (Weeding once and weeding twice) gave similar performance in weed management in the tested soil. Nevertheless, better nutrition (in terms of improved soil nutrient especially macro nutrient and organic carbon) when combined with weeding once can ascertain proper weed management and sustainable maize production. 


\section{References}

[1]. A. Javaid, R. Bajwa, N. Rabbani and T. Anjum, Comparative tolerance of six rice (Oryzasativa L.) Genotypes to allelopathy of purple nuts edge (Cyperus rotundus L.), Allelopathy Journal, (2007) 20(1): 157-166.

[2]. I. O. Akobundu, Weed Science in the tropics; Principles and Practices. A Wiley- Inter science Publications. (1987) 71 (105): 364 - 367.

[3]. M. M. Islam and M. Rahman, In: Hand book on agricultural technologies of jute, kenaf and mesta crops. Bangladesh Jute Res. Inst., Manikmia Avenue, Dhaka-1207, Bangladesh, (2008) p.82.

[4]. D. Chikoye and F. Ekeleme, Weed Flora and Soil Seedbanks in Fields Dominated by Imperata cylindrical in the Moist Savannah of West Africa, Weed Research. (2001)

[5]. J. A. Adigun, S. T. O. Lagoke and S. K. Karikari, Chemical Weed Control in Irrigated Sweet Pepper (Capsicum annuum L.), Tropical Pest Management. (1991)

[6]. D. Pimentel, L. Lach, R. Zuniga and D. Morrison, Environmental and economic costs of nonindigenous species in the United States, Journal Bioscience, (2000) 50: 53-65.

[7]. I. Heap, The International Survey of Herbicide Resistant Weeds, www.weedscience.com (May, 2014).

[8]. R. L. Zimdahl, Weed-crop competition: A review. Blackwell Publishing, Oxford, UK. (2004)

[9]. R. G. Smith, D. A. Mortensen, and Ryan, M. R. A new hypothesis for the functional role of diversity in mediating resource pools and weed-crop competition in agroecosystems, Weed Resources, (2010) 50: 37-48.

[10]. F. W. Pollnac, B. D. Maxwell and F. D. Menalled, Weed community characteristics and crop performance: a neighborhood approach, Weed Resources, (2009) 49:3.

[11]. J. E. Iken and N. A. Amusa, Maize Research and Production in Nigeria, African Journal Biotechnology, (2004) 3(6): 302-307.

[12]. IITA, International Institute of Tropical Agriculture, Ibadan, Oyo State. Annual Report on Maize Production. (2001)

[13]. International Institute of tropical Agriculture (IITA), Annual Report, (1978): pp 72 and 84

[14]. Federal Fertilizer Department (FFD), Fertilizer use and management practices for crops in Nigeria. Federal Ministry of Agriculture and Rural Development, Abuja. $4^{\text {th }}$ Edition. Chude, V.O., Olayiwola, S.O., Daudu, C. and Ekeoma, A. Eds. (2012)

[15]. Y. B. Oyeyiola, J. A. I. Omueti, N. Njoku and E. Oyekanmi, Assessment of Liming Potentials of Phosphocompost and Synthetic Fertilizers in an Acidic Alfisol for Cowpea Production. Journal of Plant and Pest Science (2014)1(2): 128 - 137.

[16]. O. I. Lungu and R. F. Dynoodt, Acidification from long term use of urea and its effects on selected soil properties. African Journal of Food, Agriculture, Nutrition and Development. (2008)8(1): 63-76. 